\section{Gastric pneumatosis: a radiological diagnosis with a wide clinical spectrum}
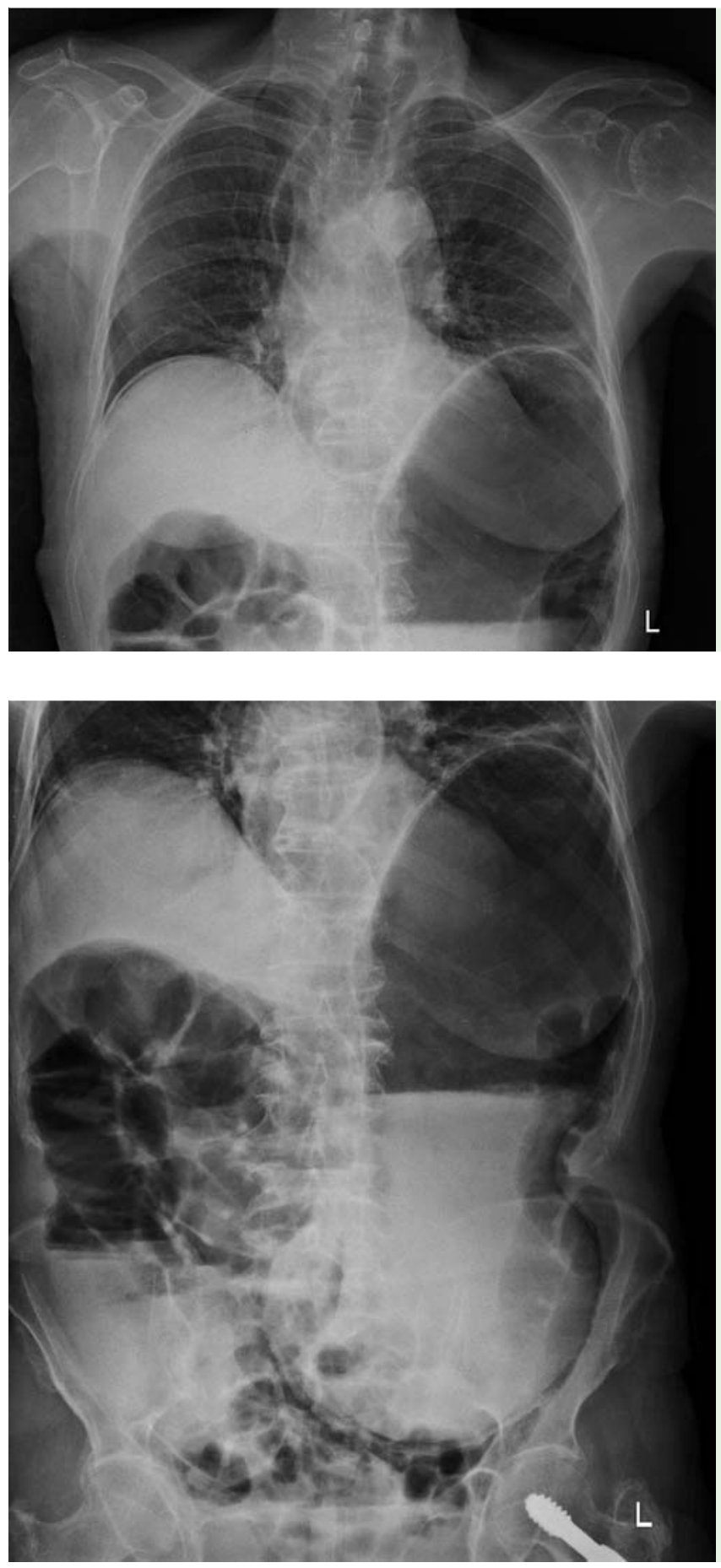

We present the case of a 72-year-old woman with a history of type 2 diabetes, ischemic stroke, and fracture of the femur. She presented to the emergency department with a 3-day history of vomiting and epigastric pain. Her physical exami-
Fig. 1 Chest radiograph in a 72-year-old woman with a 3-day history of vomiting and epigastric pain revealing massive esophageal dilatation and a small amount of free air beneath the diaphragm.

Fig. 2 Abdominal radiograph showing gastric distension with an air-fluid level and intramural gas.

nation was remarkable only for a distended but nonpainful abdomen. She had a mild leucocytosis $\left(11.3 \times 10^{9} / \mathrm{L}\right)$ and elevated C-reactive protein $(113 \mathrm{mg} / \mathrm{L})$. Radiographs of her chest ( $\bullet$ Fig. 1 ) and abdomen ( Fig.2) showed intramural gas in the gastric wall, a pneumoperitoneum, and massive esophageal dilatation. These findings were also observed in a subsequent abdominal computed tomography (CT) scan ( $\bullet$ Fig. 3 ).

Given the lack of systemic toxicity she was admitted to the ward for conservative therapy and was kept nil by mouth with intravenous hydration and proton pump inhibitor (PPI) therapy. She did not start antibiotic therapy and blood cultures were negative.

She underwent an upper gastrointestinal endoscopy, which showed erosions of the antral mucosa ( $\bullet$ Fig.4) with Helicobacter pylori-negative chronic gastritis on histology. A significant reduction of the gastric gas with disappearance of the pneumoperitoneum was documented on a repeat CT scan on day 4.The patient recovered rapidly and was discharged after 1 week. She has been asymptomatic ever since. Gastric pneumatosis is a rare radiological sign that indicates a clinical disorder with a wide spectrum of severity, which ranges from the frequently fatal emphysematous gastritis to oligosymptomatic gastric emphysema.

This case is interesting as it clearly illustrates the more benign end of the spectrum of gastric pneumatosis, which can range from this to a fulminating septic condition [1], with subacute presentations in between these extremes [2]. We feel that it is important to manage patients according to the whole clinical picture and not rely solely on imaging findings-even in the presence of traditionally ominous free intraperitoneal gas [3], which proved to be benign in our patient's case.

Endoscopy_UCTN_Code_CCL_1AB_2AD_3AF

Competing interests: None

\section{A. O. Ferreira ${ }^{1}$, A. L. Loureiro², H. T. Sousa' ${ }^{1}$, J. Brito ${ }^{3}$}

${ }^{1}$ Department of Gastroenterology, Centro Hospitalar do Barlavento Algarvio, Portimão, Portugal

${ }^{2}$ Department of Radiology, Portuguese Institute of Oncology, Lisbon, Portugal ${ }^{3}$ Department of Radiology, Centro Hospitalar do Barlavento Algarvio, Portimão, Portugal 


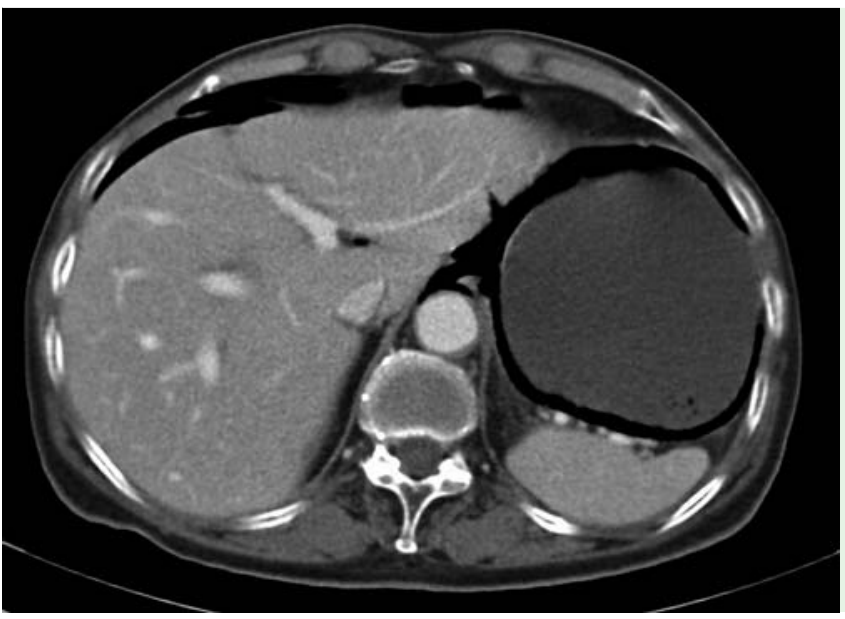

Fig.3 Abdominal computed tomography (CT) scan in portal venous phase confirming the presence of gas in the gastric wall and a small pneumoperitoneum.

\section{References}

1 Huang CT, Liao WY. Emphysematous gastritis: a deadly infectious disease. Scand J Infect Dis 2009; 41: 317-319

2 Verhelst $X$, Cabooter $M$, de Wilde $V$ et al. A case of emphysematous gastritis. Endoscopy 2012; 44: E159

3 Johnson PT, Horton KM, Edil BH et al. Gastric pneumatosis: the role of $\mathrm{CT}$ in diagnosis and patient management. Emerg Radiol 2011; 18: $65-73$

\section{Bibliography}

Dol http://dx.doi.org/

10.1055/s-0032-1325895

Endoscopy 2012; 44: E437-E438

(c) Georg Thieme Verlag KG

Stuttgart · New York

ISSN 0013-726X

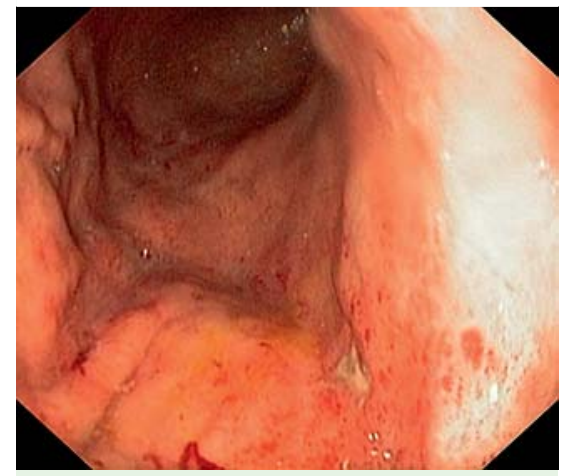

Fig. 4 Upper gastrointestinal endoscopy performed on the fourth day of conservative treatment showing erosions of the antral gastric mucosa.

\section{Corresponding author}

\section{A. O. Ferreira, MD}

Department of Gastroenterology, Centro Hospitalar do Barlavento Algarvio Sítio do Poço Seco

8500 Portimão

Portugal

alex.fsof@gmail.com 